\title{
University and Participative Democracy: Adoption, Perception and Impact - Case Study Universidad Politécnica Salesiana
}

\author{
Irene Buele ${ }^{1}$, Vidueira Pablo,"* \\ ${ }^{1}$ Department of Accounting and Auditing, Politecnica Salesiana University, Ecuador \\ ${ }^{2}$ Department of Rural Development, Technical University of Madrid, Spain
}

Copyright $(2016$ by authors, all rights reserved. Authors agree that this article remains permanently open access under the terms of the Creative Commons Attribution License 4.0 International License

\begin{abstract}
The Constitution of Ecuador was approved in 2008, and promotes the application of participatory processes for resource distribution at different levels of government. The ultimate aim of the Constitution of Ecuador is to promote sustainable development and equitable distribution of resources and wealth, and to access the "Buen Vivir". However the level of application of the methodologies supporting these processes have not been measured or evaluated. This research evaluates the participation of students of one of the leading universities of Ecuador at different stages of the methodology of participatory budgeting implemented in their location of birth or residence. The research involves the application of student surveys at the Politécnica Salesiana University, in the southern part of Ecuador. The results will determine the level of participation, perception and impact of this university community regarding the implementation of participatory budgeting within local democratic processes.
\end{abstract}

Keywords Participatory Democratic, Participatory Budgeting, Politécnica Salesiana University

\section{Introduction}

Social Participation has been reinforced during the previous years, and different methods have emerged for its application. It is considered one of the most important components for the construction of democracy and the reinforcement of public management. For Botero [1] social participation is an essential human right of every person, and a society can be considered democratic when all its citizens participate. The local governments should guarantee city participation through the implementation of spaces and effective mechanisms of democratic participation, with the power of making decisions [2].
Participative Democracy constitutes a practice of dividing the political power, the "mechanisms of participative democracy can generate synergies that improve the capacities of local government and motivate local democratic governance" [3]. Participation widens to different social actors and implies the inclusion of themes that were ignored by the political system, the redefinition of identities and links and the increasing of this participation, specially to local level [4].

According to Colino and Del Pino [5] citizen participation is an important resource that can give at least three types of benefits: from a functional point of view, it outstands the city co - responsibility with the local authorities in different social tasks, such as the pool management, museums and civic centers. It can have a positive incidence in employment and may suppose a savings in functions of organization and management of the public sector. For Colombo [6] the benefits of city participation extends to: allow to overcome the distances between citizens and politicians: permit the interactive and bidirectional communication; allow the multilevel communication in a same space without time conditions; foment the participation of groups that do not participate; facilitate the transparency; facilitate the opening of participation, mediums (forums, chats...); mark down the cost of participation.

The participation of the young population is important for democracy. Youth Participation in the formulation of a participative budget permits that the young people be conscious about the necessities of their city to sum up efforts for sustainable and equitable development. According to Beretta, Turra, Ferrero [2] the implementation of a young participative budget has as objectives: to expand the capacities of the young people to get a better social and political inclusion from recognizing their rights as citizens, and; to reinforce the relationships between the local Government, democratic processes, young organizations and the society in general. 
However, the young population lacks interest in participating in these processes. From these aspects Rendón [7] remarks: the incidence of the young citizens in the processes of construction of public politics, the real level of participation, and the importance of their formation for demanding and exercising their rights from an effective participation. The research measures the participatory experience of students of the Politécnica Salesiana University (UPS), dispersed among 16 undergraduate programs. The survey assesses their experience in developing the participatory budget 2015 of their place of residence or birth [8-17].

\section{Materials and Methods}

To determine the perception, level of participation of the university students in the methodology of participative budget for their location, it was necessary to follow the subsequent procedure: 1) selection of the sample, 2) design and application of a questionnaire, 3) tabulation and analysis of the results.

Students from the Politécnica Salesiana University, Cuenca campus were taken as the population sample. The population of this campus is 6055 , and worked with a confidence level of $90 \%$ and a sample error of $3,89 \%$. Students from the Politécnica Salesiana University of
Cuenca have been selected as population for this research due to: UPS is located in the zone of greater application of participatory budgeting in Ecuador; university students are young people who meet or just turned of age to participate in different processes as citizens; young people are aware of the new methods, especially technology, citizen participation is important to measure their perception considering future professionals who will eventually be in charge of participatory budgeting in their location.

The survey applied to the university students was made through a Google questionnaire from Google Drive and the link was sent to each student's e - mail. Considering as Colombo [6] gives information, that the incorporation of internet has allowed the improvement of government management processes information and services to the citizens. Even though it is far from offering possibilities of interaction or debate, it is of great utility.

\section{Results}

The results permit us to determine the level of participation of the university students in methodologies as the participative budget. It also allows us to have a general vision of their perception regarding the legislation and process of participative democracy.

Table 1. Knowledge of the Constitution and its principles by gender and age.

\begin{tabular}{|c|c|c|c|c|c|c|c|c|}
\hline \multirow[b]{3}{*}{ Female } & \multicolumn{4}{|c|}{$\begin{array}{l}\text { Did you know that the current Constitution of the } \\
\text { Republic of Ecuador promotes the creation of spaces } \\
\text { for direct participation of its citizens? }\end{array}$} & \multicolumn{4}{|c|}{$\begin{array}{l}\text { Did you know that one of the principles and powers of } \\
\text { the Decentralized Autonomous Governments is the } \\
\text { city participation? }\end{array}$} \\
\hline & \multicolumn{2}{|c|}{ No } & \multicolumn{2}{|c|}{ Yes } & \multicolumn{2}{|c|}{ No } & \multicolumn{2}{|c|}{ Yes } \\
\hline & 58 & & 96 & & 53 & & 101 & \\
\hline $17-21$ & 40 & $69 \%$ & 58 & $60 \%$ & 32 & $60 \%$ & 66 & $65 \%$ \\
\hline $22-26$ & 15 & $26 \%$ & 23 & $24 \%$ & 15 & $28 \%$ & 23 & $23 \%$ \\
\hline $27-31$ & 2 & $3 \%$ & 8 & $8 \%$ & 3 & $6 \%$ & 7 & $7 \%$ \\
\hline $32-36$ & 0 & $0 \%$ & 2 & $2 \%$ & 0 & $0 \%$ & 4 & $4 \%$ \\
\hline $37-41$ & 1 & $2 \%$ & 2 & $2 \%$ & 1 & $2 \%$ & 0 & $0 \%$ \\
\hline $42-46$ & 0 & $0 \%$ & 2 & $2 \%$ & 1 & $2 \%$ & 0 & $0 \%$ \\
\hline $47-54$ & 0 & $0 \%$ & 1 & $1 \%$ & 1 & $2 \%$ & 1 & $1 \%$ \\
\hline Male & 117 & & 146 & & 109 & & 154 & \\
\hline $17-21$ & 64 & $55 \%$ & 84 & $58 \%$ & 70 & $64 \%$ & 78 & $51 \%$ \\
\hline $22-26$ & 42 & $36 \%$ & 51 & $35 \%$ & 32 & $29 \%$ & 61 & $40 \%$ \\
\hline $27-31$ & 8 & $7 \%$ & 5 & $3 \%$ & 6 & $6 \%$ & 7 & $5 \%$ \\
\hline $32-36$ & 1 & $1 \%$ & 3 & $2 \%$ & 0 & $0 \%$ & 4 & $3 \%$ \\
\hline $37-41$ & 2 & $2 \%$ & 2 & $1 \%$ & 1 & $1 \%$ & 3 & $2 \%$ \\
\hline $42-46$ & 0 & $0 \%$ & 0 & $0 \%$ & 0 & $0 \%$ & 0 & $0 \%$ \\
\hline $47-52$ & 0 & $0 \%$ & 1 & $1 \%$ & 0 & $0 \%$ & 1 & $1 \%$ \\
\hline
\end{tabular}


When consulting the university students about their knowledge regarding the Constitution of the Republic, and about city participation, not only men, but also women, express to know about the creation of places for direct participation of the citizens, as well as the principles and powers of the Decentralized Autonomous Governments. However, the women are the ones who present a greater knowledge percentage wise regarding these facts.

The women who answered these questions were between 17 and 54 years old as age range. Corresponded to the $60 \%$ who were between the 17 and 21 years old age range. They manifested to know about what is expressed in the Constitution of the Republic regarding the creation of spaces for the direct city participation. Whereas $69 \%$ answered negatively because they did not have any knowledge about the Constitution of the Republic. The men who answered the questionnaire were between 17 and 52 years old. 58\% were aged between 17 and 20. They manifested to know about what is expressed in the Constitution of the Republic regarding the creation of places for direct city participation. Meanwhile 55\% answered negatively by saying that they did not have any knowledge regarding the Constitution of the Republic.

Regarding the knowledge about the principles and powers of the Decentralized Autonomous Governments in citizen participation, $65 \%$ of women answered positively were between 17 and 21 years old. Whereas $60 \%$ corresponded to the ones who said they have no knowledge about the principles and powers of the Decentralized Autonomous Governments. 51\% men manifested knowledge about the principles and powers of the Decentralized Autonomous Governments in citizen participation. 64\% corresponds to the ones who answered by saying they had no knowledge about the principles and powers of the Decentralized Autonomous Governments in the city participation. They ones answering this way were between 17 and 21 years.

Table 2. Knowledge of the participative budget by gender

\begin{tabular}{|c|c|c|c|c|c|c|c|c|c|c|}
\hline \multirow[b]{3}{*}{ Female } & \multicolumn{5}{|c|}{$\begin{array}{c}\text { Do you know what the methodology of participative } \\
\text { budget consists on? }\end{array}$} & \multicolumn{5}{|c|}{$\begin{array}{l}\text { Do you know the phases that imply a process of } \\
\text { Participative Budget? }\end{array}$} \\
\hline & \multicolumn{2}{|c|}{ No } & \multicolumn{2}{|c|}{ Yes } & \multirow{2}{*}{$\begin{array}{c}\text { Total } \\
154 \\
\end{array}$} & \multicolumn{2}{|c|}{ No } & \multicolumn{2}{|c|}{ Yes } & \multirow{2}{*}{$\begin{array}{c}\text { Total } \\
154 \\
\end{array}$} \\
\hline & 130 & $84 \%$ & 24 & $16 \%$ & & 138 & $90 \%$ & 16 & $10 \%$ & \\
\hline Male & 218 & $83 \%$ & 45 & $17 \%$ & 263 & 226 & $86 \%$ & 37 & $14 \%$ & 263 \\
\hline
\end{tabular}

Regarding the level of knowledge with respect to the methodology of a participative budget, men as well as women remark, as a majority, not knowing what it consists on or its phases. In these questions, the men were the ones greater knowledge. The students who answered affirmatively by saying they knew what the methodology of participative budget consists on belong to the provinces of Azuay, Carchi, Cañar, Loja, Morona Santiago and Zamora Chinchipe. Students from the provinces from the coastal region, such as Manabí, Santa Elena, and El Oro also answered this inquiry, but they said they do not know anything regarding this methodology. Only the students from Azuay, Carchi, Cañar, Loja, and Zamora Chinchipe manifested to know the phases of the participative budget.

Table 3. Application of the participative budget

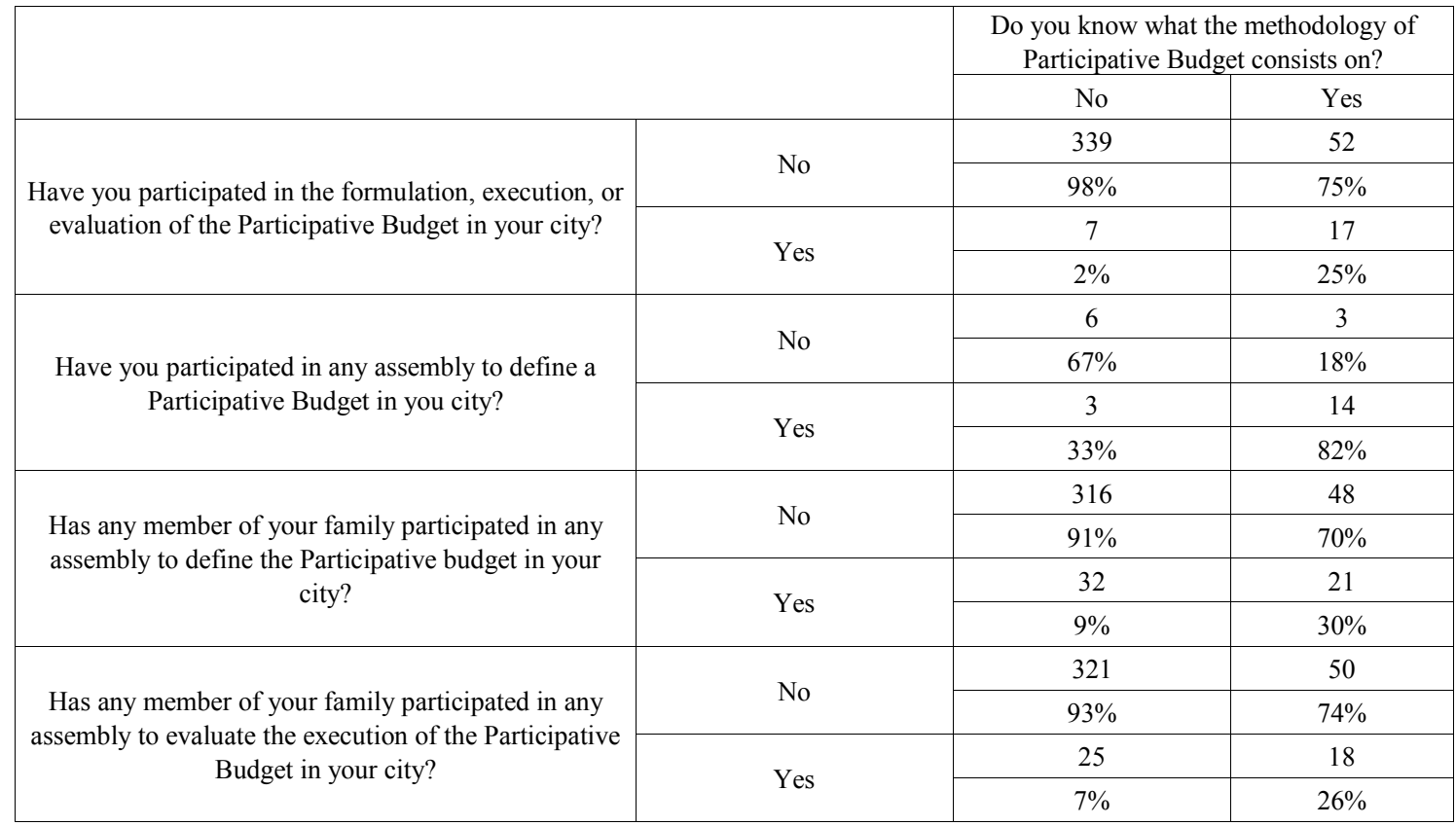


From the students who manifested to have a previous knowledge about the methodology of a participative budget, $25 \%$ mentioned to have participated in the processes of formulation, execution, or evaluation of the participative budget for their city. An application was observed in the provinces of Azuay, Loja and Morona Santiago, specifically in the cantons Chordeleg, Cuenca, Girón, Gualaquiza, Loja, Santa Isabel, Sigsig and Yanuncay. Likewise, form all the affirmative answers from the students that know about the methodology of a participative budget, $82 \%$ mentions to have participated in any assembly to define the participative budget. These students belong to the provinces of Azuay, Loja, and Morona Santiago. From the students who know the methodology of participative budget, $30 \%$ said that any relative has participated in any assembly to establish the participative budget, mentioning the participation of their grandparents, mother, father, where the mother and the father are the ones who have mainly participated with $33 \%$ of participation respectively. During the assembly of evaluation of the participative budget, the participation of the mother and the father is incremented in a $39 \%$, whereas the participation of the rest of the family members is reduced.

From the students who manifested to have participated in any of the phases of the participative budget, $7 \%$ have said as qualified it as very satisfactory. $71 \%$ have qualified the process as satisfactory, $14 \%$ somehow satisfactory and $7 \%$ unsatisfactory. The university students mention to have given this qualification according to: the results generated for the community, work efficiency, no unified agreement was reached have, the distribution of the economic resources, that have to be destined to the rural area do not cover the expectations of the population, the particular interests of the citizens domain, priorities are not defined, lack of abilities and techniques from the responsible ones to get to the population.

From the people who answered they ignore the methodology of a participative budget, 98\% have not participated in any phase of this type of methodology, $67 \%$ not participated in any assembly for its definition, of the $91 \%$ no family member has participated in any of the phases and $93 \%$ of the family members have not participated in any meeting. They mentioned they have not participated in these activities for the reason that $73 \%$ were unaware of the existence of a process of this type, $12 \%$ thought it was intended to other people, $9 \%$ were sure that the participative budget is not done in their area and $15 \%$ posted not having completed it due to lack of information.

When consulting students about the efforts of the Politécnica Salesiana University to motivate them to increase their participation, $65 \%$ of the surveyed students stressed the need to actively participate in decision-making at internal, local, regional or national levels and $67 \%$ said that the university creates places to encourage an active citizenship participation in internal university decision-making.

It was observed that participation in a democratic process in the context of a participative budget has not depended on the student's professional area. As a result, it can be perceived that Local Management for Sustainable Development Career that is directly linked to these processes as well as Electronic Engineering Career which is distant from these processes obtained the same results. The participation of students in this process is only $6 \%(24 / 415)$.

Table 4. Application of participative budget per careers

\begin{tabular}{ccccc}
\hline & \multicolumn{3}{c}{ Have you participated in the formulation, implementation or evaluation of a } \\
Participative Budget in your area? & Yes \\
\hline & No & $11 \%$ & 4 & $17 \%$ \\
\hline Accounting and Auditing & 43 & $16 \%$ & 1 & $4 \%$ \\
\hline Automotive Engineering & 62 & $3 \%$ & 0 & $0 \%$ \\
\hline $\begin{array}{c}\text { Biotechnology Engineering } \\
\text { Resources }\end{array}$ & 10 & $12 \%$ & 1 & $4 \%$ \\
\hline Business Administration & 47 & $10 \%$ & 1 & $4 \%$ \\
\hline Electric Engineering & 41 & $9 \%$ & 5 & $21 \%$ \\
\hline Electronic Engineering & 36 & $4 \%$ & 0 & $0 \%$ \\
\hline Environmental Engineering & 17 & $4 \%$ & 0 & $0 \%$ \\
\hline Labor psychology & 17 & $1 \%$ & 5 & $21 \%$ \\
\hline Local Management for Sustainable & 4 & $4 \%$ & 1 & $4 \%$ \\
\hline Development & 14 & $2 \%$ & 3 & $13 \%$ \\
\hline Mechanical Engineering & 9 & $4 \%$ & 2 & $8 \%$ \\
\hline Mechatronics Engineering & 14 & $3 \%$ & 1 & $4 \%$ \\
\hline Pedagogy & 11 & $5 \%$ & 0 & $0 \%$ \\
\hline Physical Education & 19 & $9 \%$ & 0 & $0 \%$ \\
\hline Social Communication & 36 & $3 \%$ & 0 & $0 \%$ \\
\hline Systems Engineering & 11 & & 24 & \\
\hline Total & 391 & & $5 \%$ \\
\hline
\end{tabular}




\section{Conclusions}

$58 \%$ of surveyed students know that the Constitution of the Republic of Ecuador in effect promotes the creation of places for direct participation of citizens and $61 \%$ know that one of the principles and powers of the Decentralized Autonomous Governments is citizen participation. Considering the responses of men and women, it is women showing an increased understanding between 6-7 points higher than those reported by men.

When consulting students that show how much they know about the methodology of a participative budget and its phases, the general response indicated a lack of knowledge regarding the topic between $83 \%$ to $90 \%$; however, this time men mentioned they have a greater knowledge about methodology with $4 \%$, while women participated in $2 \%$.

Politécnica Salesiana University, Office Cuenca, has direct influence in the province of Azuay. Students mentioned they have been in participative budget processes in only $47 \%$ of the counties of this province (7 of 15 provinces): Chordeleg, Cuenca, El Pan, Gualaceo, Nabón, Sigsig and Santa Isabel.

Disinterest and apathy for politics embrace most of the population regardless of their age; situation that extends to the students of the Politécnica Salesiana University. This situation arises due to the distrust towards politics, especially its institutions, actors, performance and the rejection to political-ideological traditional affiliation. Activities that motivate young people to be active actors in decision making for their location are required, so that their strengths and social contribution are visible.

The Constitution of Ecuador in Art. 204 mentions "people are the principal and first auditors of public power, in the exercise of their right to participation", the Organic Code of Territorial Organization Autonomy and Decentralization in Art. 3, paragraph g) considers citizen participation as a right that must be "respected, promoted and facilitated by all state institutions mandatorily, with the objective of to ensure the development and shared decision-making between different levels of government and citizenship as well as shared management and social control of plans, policies, programs and public projects, design and implementation of participatory budgets of governments" and the Law Citizen Participation Art. 1 mentions "the law is intended to encourage, promote and guarantee the exercise of the rights of participation of citizens and citizens, collectives, communes, communities, indigenous peoples and nationalities, Afro-Ecuadorian peoples and montubio, and other forms of lawful organization playing a leading role in making appropriate decisions, autonomous collective organization and effective forms of governance with the participation of citizens; to institute instances, mechanisms, instruments and procedures of public deliberation between the state, at different levels of government and society, to monitor public policies and the provision of public services; strengthen citizen power and their forms of expression; and it set the stage for the functioning of participatory democracy, as well as initiatives accountability and social control". These laws based citizen participation, however there are no laws that clearly mark as implemented in the institutions of Ecuador. The municipalities have expressed interest in establishing procedures for determining their budgets, however, they are of the few entities concerned in its implementation. Universities have had little or no interest in contributing to the strengthening of the culture of citizen participation. The Politécnica Salesiana University has extensive coverage in Ecuador, however, it has not generated impact projects that promote citizen participation. Students are passive and have no interest in the national reality. Citizen participation in Ecuador is emerging.

\section{Acknowledgements}

Sincere thanks to the authorities of the Politécnica Salesiana University for your help and permission to apply surveys.

\section{REFERENCES}

[1] P. Botero, "Perspectivas teóricas para comprender la categoría participación ciudadana-política juvenil en Colombia," Revista Latinoamericana de Ciencias Sociales Niñez y Juventud, pp. 656-611 , 2008.

[2] D. Berretta, S. Turra and M. Ferrero, "Prespuesto Participativo Joven," s.f. [Online]. Available: http://www.rosario.gov.ar/sitio/verArchivo?id=4342\&tipo $=0$ bjetoMultimedia. [Accessed 18 Noviembre 2015].

[3] E. Conejero, "Globalización, gobernanza local y democracia participativa," Nuevos retos para las administraciones locales y autonómicas en España, pp. 13-31, 2005.

[4] L. Avritzer and B. De Sousa Santos, "Para ampliar el canon democrático," 2015. [Online]. Available: http://www.eurozine.com/articles/article_2003-11-03-santoses.html. [Accessed 15 Noviembre 2015].

[5] C. Colino and E. Del Pino, "Democracia Participativa el nivel local: Debates y Experiencias en Europa," Revista catalana de dret públic, pp. 247-283, 2008.

[6] C. Colombo, "Innovación democrática y TIC, ¿Hacia una democracia participativa?," Revista de los Estudios de Derecho y Ciencia Política de la UOC, pp. 28-40, 2006.

[7] A. Rendón, "Los retos de la democracia participativa," Sociológica, pp. 183-211 187, 2004.

[8] A. M. Fernández, "España-México: democracia, interés político y asociacionismo juvenil," El Cotidiano, pp. 115-120, 2009.

[9] J. F. Aguirre Sala, "El potencial de los medios digitales ante la participación ciudadana tradicional y en el presupuesto participativo," Comunicación y Sociedad, pp. 211-229, 2014. 
[10] A. R. Corona, "Justicia distributiva: el presupuesto participativo en Porto Alegre, Brasil," Polis: Investigación y Análisis Sociopolítico y Psicosocial, p. 2(1), 2006.

[11] A. Díaz Hurtado, "Presupuesto municipales, participación y reordenamiento de los espacios políticos," Íconos, pp. 27-38, 2009.

[12] R. S. E. Carrillo-Larco, "Participative budget: Do the most vulnerable regions invest it in health care?," Revista Peruana de Medicina Experimental y Salud Publica, pp. 583-584, 2012.

[13] H.-S. Yoo and Gimyeseung, "Current State on Civil Participatory Budget System and Policy Agenda: In Case of Civil Participatory Budget System in Gyeonggi Province," The Journal of Corean Policy Studies, pp. 243-260, 2012.
[14] Z. H. J. Wang, "The effect of congruence between cultural time orientation and budget planning horizon on employees' satisfaction with participative," Advances in Accounting Behavioral Research, pp. 91-116, 2011.

[15] B. Wampler, "Expanding accountability through participatory institutions: Mayors," Latin American Politics and Society, pp. 73-99, 2004.

[16] E. G. a. F. Frances, "The deliberative turn in participation: the problem of inclusion and deliberative opportunities in participatory budgeting," European Political Science Review, pp. 283-302, 2012.

[17] B. Kim, "Local Finance Management and Resident's Participatory System - focusing on the Open System of Local Finance Information and Resident's Participatory Budgeting -," Public Law Journal, pp. 119-132, 2006. 